\title{
ASSOCIATION OF CIRCADIAN RHYTHM WITH MYOCARDIAL INFARCTION
}

\author{
Ivana Škrlec ${ }^{1,2}$, Jakov Milić ${ }^{1}$, Marija Heffer ${ }^{1}$, Robert Steiner ${ }^{3}$, Borut Peterlin ${ }^{4}$ and Jasenka Wagner ${ }^{1}$ \\ ${ }^{1}$ Department of Medical Biology and Genetics, Faculty of Medicine, Josip Juraj Strossmayer University of Osijek, \\ Osijek, Croatia; ${ }^{2}$ Department of Biology and Chemistry, Faculty of Dental Medicine and Health, Josip Juraj \\ Strossmayer University of Osijek, Osijek, Croatia; ${ }^{3}$ Division of Cardiovascular Diseases and Intensive Care, \\ Department of Internal Medicine, Osijek University Hospital Centre, Osijek, Croatia; \\ ${ }^{4}$ Clinical Institute of Medical Genetics, University Medical Center Ljubljana, Ljubljana, Slovenia
}

\begin{abstract}
SUMMARY - Cardiovascular diseases are the world's leading cause of death. Human physiologic activities and state during illness are under the control of circadian rhythm. The aim of the study was to determine the potential association of chronotype and daytime sleepiness with susceptibility to myocardial infarction. We conducted a case-control study on 200 patients hospitalized due to myocardial infarction and 200 healthy controls. Systematic information on the past and present medical history was obtained from all participants. Chronotype was assessed using the Morningness-Eveningness Questionnaire (MEQ), and daytime sleepiness was assessed by the Epworth Sleepiness Scale (ESS). The mean age of the study population was $64 \pm 13$ years, and $54.5 \%$ were male. There was no significant difference in MEQ (58.88 \pm 6.52 vs. $58.46 \pm 7.78, \mathrm{p}=0.601$ ) or ESS (5 (interquartile range, IQR 4-7.5) vs. 6 (IQR 3-8), $\mathrm{p}=0.912$ ) score between patients and controls. Nevertheless, we found statistically significant differences related to risk factors for cardiovascular diseases, such as hypertension, dyslipidemia, and diabetes mellitus. However, there was no association of MEQ and ESS score with myocardial infarction in the study population.
\end{abstract}

Key words: Cardiovascular diseases; Circadian rhythm; Myocardial infarction; Cause of death; Croatia

\section{Introduction}

According to the World Health Organization, cardiovascular diseases (CVD) are the world's leading cause of death, accounting for 17.5 million deaths annually, of which ischemic heart disease caused 7.3 million deaths ${ }^{1}$. In Croatia, myocardial infarction (MI) is the third leading cause of death ${ }^{2}$. Although numerous studies on MI have been conducted, its etiology remains largely unknown ${ }^{3}$.

Circadian rhythms are associated with many cardiovascular parameters ${ }^{4}$. Human physiologic activities and state during illness are under the control of circa-

Correspondence to: Ivana Škrlec, $M D, P h D$, Department of Biology and Chemistry, Faculty of Dental Medicine and Health, Crkvena 21, HR-31000 Osijek, Croatia

E-mail: iskrlec@fdmz.hr

Received March 27, 2017, accepted February 16, 2018 dian rhythm, which controls physiology at multiple levels, from gene expression to complex behaviors ${ }^{5-7}$. The effect of circadian rhythm on acute MI has been the subject of considerable scientific interest ${ }^{8}$. Sleep is one of the main requirements for the normal psychophysical functioning of every person ${ }^{9}$, especially needed in situations of physical and psychological stress. Sleep disorders are common phenomena in modern society with the prevalence rising to $11.9 \%$, and they are associated with vascular outcomes such as $\mathrm{MI}^{10}$. Humans can be categorized into different circadian phenotypes (chronotypes) depending on their preferred time of sleep and wakefulness ${ }^{11}$.

One study showed that daytime sleepiness was an independent risk factor for cardiovascular events ${ }^{12}$, but there are no studies regarding chronotype as a risk factor for MI or CVD. There is little research done regarding this issue, and there are only a few studies in 
the population of MI patients ${ }^{13,14}$. Some cardiovascular risk factors, such as diabetes and hypertension, are associated with chronotype and sleep ${ }^{13}$, while diabetes, smoking, and reinfarction can modify the circadian rhythm ${ }^{15}$. Circadian clocks are altered in animal models with increased CVD risk, including aging, diet-induced obesity, diabetes, hypertension, simulated shift work, and ischemia ${ }^{16}$. Circadian desynchrony of the body from its environment, either through rotating shift-work schedules or genetic alteration, augments the development of $\mathrm{CVD}^{16}$.

Therefore, we hypothesized that MI might be associated with chronotype and daytime sleepiness in humans. To test the hypothesis, we performed a casecontrol study on a population of MI patients in comparison with a control population.

\section{Materials and Methods}

\section{Participants}

Patients with MI were hospitalized at the Department of Cardiovascular Diseases and Intensive Care, Osijek University Hospital Centre in Osijek, Croatia.

Thygesen et al. defined MI by the presence of at least two of the following: typical increase of biochemical marker of myocardial necrosis - cardiac troponin $\mathrm{T}$ (above the $99^{\text {th }}$ percentile), ischemic chest pain symptoms lasting for more than 30 minutes, and electrocardiography (ECG) changes indicative of ischemia (ST-segment elevation or depression $)^{17}$. Patients were excluded from this study if they did not meet the above criteria or if they had a percutaneous coronary intervention or coronary artery bypass grafting.

The control group consisted of 200 healthy sexand age-matched participants, whose medical documentation did not show any history of CVD. They were selected by their own primary care physician. We excluded any patient relatives from the control group because, according to large studies, approximately 50\% of the chronotype features are estimated to be heritable $^{18,19}$.

The study was approved by the Ethics Committee of the Faculty of Medicine, Josip Juraj Strossmayer University of Osijek (No. 2158-61-07-12-21) and by the Ethics Committee of the Osijek University Hospital Centre (No. 25-1:3160-3/2012). The study was conducted according to the Declaration of Helsinki and its amendments. A written informed consent was obtained from all study participants.

\section{Questionnaires}

Systematic information on the past and present medical history was collected from all participants. The questionnaire included questions on age, education, employment, caffeine consumption, history of smoking, family history of MI, former CVD, hypertension, dyslipidemia, respiratory diseases, diabetes mellitus types 1 and 2, thyroid gland diseases, kidney and liver diseases. Hypertension was defined as a history of hypertension of more than two years requiring initiation of antihypertensive therapy prescribed by primary physicians. Dyslipidemia was defined as having a reported history of elevated fasting concentration of total cholesterol or triglycerides. Diabetes mellitus was defined as reported diabetes or receiving oral hypoglycemic agent treatment or insulin treatment. Positive family history of CVD was defined as evidence of coronary artery disease in first-degree relatives before 60 years of age, such as a history of MI, coronary artery bypass surgery, and angina pectoris. Former CVD was defined as a reported history of angina pectoris, MI, arrhythmia or stroke in the patient group. All given information was checked in the patient medical records.

Chronotype was assessed with the MorningnessEveningness Questionnaire (MEQ) in the hospital after the patient medical condition had been stabilized $^{20,21}$. MEQ classifies participants scored between 59 and 86 as morning types, those scored between 42 and 58 as intermediate types, and those scored 16-41 as evening types. The scores were added, and the sum was converted into a three-point MEQ scale.

Daytime sleepiness was assessed using the Epworth Sleepiness Scale (ESS, contact information and permission to use: Mapi Research Trust, Lyon, France $)^{22,23}$. Participants were asked how often would they say they doze off or fall asleep in the following situations: sitting and reading, watching TV, sitting inactive in a public place, as a passenger in a car for an hour without break, lying down to rest in the afternoon, sitting and talking to someone, sitting quietly after lunch without alcohol, and in a car while stopped for a few minutes in the traffic. For each of these eight situations, responses were recorded on a scale of 0 to 3 and coded as follows: 0 = never doze, $1=$ slight chance, 
Table 1. Demographic and general characteristics of all study participants according to groups

\begin{tabular}{|l|l|l|l|l|}
\hline \multirow{2}{*}{ Variable } & \multicolumn{2}{|c|}{ Patients } & \multicolumn{2}{c|}{ Controls } \\
\cline { 2 - 5 } & Male (n=114) & Female $(\mathrm{n}=86)$ & Male $(\mathrm{n}=104)$ & Female $(\mathrm{n}=96)$ \\
\hline Age (yrs), mean (SD) & $64(12)$ & $69(12)$ & $62(13)$ & $62(13)$ \\
\hline Smoking: & $\mathrm{n}(\%)$ & $\mathrm{n}(\%)$ & $\mathrm{n}(\%)$ & $\mathrm{n}(\%)$ \\
non-smoker & $41(35.9)$ & $58(67.4)$ & $70(67.3)$ & $81(84.4)$ \\
smoker & $25(21.9)$ & $16(18.6)$ & $26(25)$ & $13(13.5)$ \\
former smoker & $48(42.2)$ & $12(13.9)$ & $8(7.7)$ & $2(2.1)$ \\
\hline Education: & & & & \\
elementary & $19(16.7)$ & $51(59.3)$ & $16(15.4)$ & $37(38.5)$ \\
secondary & $77(67.5)$ & $29(33.8)$ & $70(67.3)$ & $44(45.8)$ \\
college/university & $18(15.8)$ & $6(6.9)$ & $18(17.3)$ & $15(15.7)$ \\
\hline Work status: & & & & \\
employed & $25(21.9)$ & $7(8.2)$ & $30(28.9)$ & $27(28.1)$ \\
unemployed & $11(9.7)$ & $12(13.9)$ & $7(6.7)$ & $6(6.3)$ \\
retired & $78(68.4)$ & $67(77.9)$ & $67(64.5)$ & $63(65.6)$ \\
\hline Caffeine consumption: & & & & \\
yes & $99(86.8)$ & $72(83.7)$ & $82(78.9)$ & $67(69.8)$ \\
no & $15(13.2)$ & $14(16.3)$ & $22(21.1)$ & $29(30.2)$ \\
\hline
\end{tabular}

Numerical variables are presented as mean (SD), and categorical variables as number (percentage)

$2=$ moderate chance, and $3=$ high chance. The ESS score for each participant was simply the sum of the results for their eight responses (range 0-24), and the sum was converted into four types of daytime sleepiness.

\section{Data analyses}

Data were expressed as absolute frequencies with percentages, means with standard deviations (SD), and medians with interquartile range (IQR), where appropriate. Mann-Whitney U test was used to test differences between disease status and chronotype and daytime sleepiness. The analyses were performed separately for women and men because of the sex difference in cardiovascular morbidity and mortality and the differential self-reporting of sleep habits between women and men supported in previous studies ${ }^{12}$. Risk factors for CVD such as smoking, hypertension and dyslipidemia were compared with the MEQ and ESS scores by Pearson $\chi^{2}$-tests. The level of statistical significance was set at $\mathrm{p}<0.05$, and all significant values were assessed after Bonferroni correction for the number of independent hypotheses tested. All analyses were performed using Statistica 12 (StatSoft, Inc., version 12, Tulsa, OK, USA) system for Windows.

\section{Results}

Demographic and general characteristics of the study sample are summarized in Table 1 .

The mean age of the study population was $64 \pm 13$ years, and $54.5 \%$ were males.

In female patients and controls, a significant difference was found in smoking and age $\left(\chi^{2}=103.9, \mathrm{df}=76\right.$, $\mathrm{p}=0.018$ and $\chi^{2}=129.8, \mathrm{df}=74$, respectively; $\mathrm{p}<0.001$ ), while there was no significant difference in smoking and age in male patients and controls $\left(\chi^{2}=89.9, \mathrm{df}=88\right.$, $\mathrm{p}=0.421$ and $\left.\chi^{2}=89.5, \mathrm{df}=88 ; \mathrm{p}=0.435\right)$. The prevalence of cardiovascular risk factors among study participants is shown in Table 2.

Between-group comparisons revealed that three chronotype groups and three ESS groups were similar according to age and gender. Half (50.5\%) of the MI patients were of intermediate chronotype, while only a small part $(0.5 \%)$ was of evening chronotype (Table 3 ). There was no significant difference between patients and controls in daytime sleepiness (5 (IQR, 4-7.5) vs. 6 (IQR, 3-8), $Z=0.11 ; p=0.912$ ) (Table 4). There was no statistically significant difference in the ESS and MEQ scores between genders in patient and control groups. 
Table 2. Prevalence of cardiovascular risk factors among study participants

\begin{tabular}{|l|l|l|l|l|l|}
\hline \multirow{2}{*}{ Characteristic } & \multicolumn{2}{l|}{ Patients } & \multicolumn{2}{l|}{ Controls } & \\
\cline { 2 - 5 } & Male $(\mathrm{n}=114)$ & Female $(\mathrm{n}=86)$ & Male $(\mathrm{n}=104)$ & Female (n=96) & p value \\
\cline { 2 - 5 } & $\mathrm{n}(\%)$ & $\mathrm{n}(\%)$ & $\mathrm{n}(\%)$ & $\mathrm{n}(\%)$ & \\
\hline Hypertension & $57(50)$ & $50(58.1)$ & $27(25.9)$ & $32(33.3)$ & $<\mathbf{0 . 0 0 1}$ \\
Dyslipidemia & $9(7.9)$ & $17(19.8)$ & $9(8.7)$ & $14(14.6)$ & $\mathbf{0 . 0 4 8}$ \\
Respiratory disease & $2(1.8)$ & 0 & $3(2.9)$ & $5(5.2)$ & 0.772 \\
Diabetes mellitus type 1 & $1(0.9)$ & $1(1.2)$ & $2(1.9)$ & 0 & 0.886 \\
Diabetes mellitus type 2 & $26(22.8)$ & $18(20.9)$ & 0 & 0 & $<.0 .001$ \\
Thyroid gland disease & $2(1.8)$ & $6(6.9)$ & 0 & $6(6.3)$ & 0.612 \\
Kidney disease & $4(3.5)$ & $11(12.8)$ & $7(6.7)$ & $5(5.2)$ & 0.910 \\
Liver disease & $1(0.9)$ & $9(10.5)$ & $4(3.9)$ & $5(5.2)$ & 0.481 \\
Positive family history of CVD & $29(25.4)$ & $18(20.9)$ & $12(11.5)$ & $15(15.6)$ & 0.754 \\
History of former CVD & $82(71.9)$ & $61(70.9)$ & $7(6.7)$ & $7(7.3)$ & 0.221 \\
Myocardial infarction & $37(32.5)$ & $20(23.3)$ & 0 & 0 & - \\
Other (arrhythmia, angina pectoris, stroke) & $45(39.5)$ & $41(47.7)$ & $7(6.7)$ & $7(7.3)$ & - \\
None & $32(28.1)$ & $25(29.1)$ & $97(93.3)$ & $89(92.7)$ & - \\
\hline
\end{tabular}

$\mathrm{p}$ values are for MI patients versus controls. Family history of cardiovascular disease (CVD) was defined as evidence of coronary artery disease in first-degree relatives before 60 years of age. History of former CVD was defined as reported history of angina pectoris, myocardial infarction, arrhythmia or stroke in patient group; variables are presented as frequency (percentage)

Table 3. Chronotype distribution among participants

\begin{tabular}{|l|l|l|l|l|}
\hline & $\begin{array}{l}\text { Evening type } \\
\text { (score 16-41) }\end{array}$ & $\begin{array}{l}\text { Neither type } \\
\text { (score 42-58) }\end{array}$ & $\begin{array}{l}\text { Morning type } \\
\text { (score 59-86) }\end{array}$ & p value* \\
\hline $\begin{array}{l}\text { Patients } \\
\text { Controls }\end{array}$ & $1(0.5 \%)$ & $101(50.5 \%)$ & $98(49 \%)$ & 0.601 \\
\hline p value* & $2(1 \%)$ & $101(50.5 \%)$ & $97(48.5 \%)$ & \\
\hline
\end{tabular}

*Mann-Whitney U test

Table 4. Distribution of daytime sleepiness among participants

\begin{tabular}{|l|l|l|l|l|l|}
\hline & $\begin{array}{l}\text { Normal sleepiness } \\
(\text { score 0-10) }\end{array}$ & $\begin{array}{l}\text { Mild sleepiness } \\
(\text { score 11-14) }\end{array}$ & $\begin{array}{l}\text { Moderate sleepiness } \\
(\text { score 15-18) }\end{array}$ & $\begin{array}{l}\text { Severe sleepiness } \\
\text { (score 19-24) }\end{array}$ & p value* $^{*}$ \\
\hline Patients & $182(91 \%)$ & $18(9 \%)$ & 0 & 0 & 0.912 \\
\hline Controls & $177(88.5 \%)$ & $20(10 \%)$ & $3(1.5 \%)$ & 0 & \\
\hline p value* & 0.510 & 0.795 & - & - & \\
\hline
\end{tabular}

*Mann-Whitney U test

A significant difference was found in female patients of intermediate chronotype and diabetes mellitus type $2\left(\chi^{2}=21.60, \mathrm{df}=12 ; \mathrm{p}=0.042\right)$, as well as in the ESS score of normal sleepiness and age $(Z=1.99$; $\mathrm{p}=0.044)$. The reference range of normal daytime sleepiness score is $0-10$. Normal daytime sleepiness had a protective effect on the CVD risk factors in male patients, such as hypertension (OR, 0.81 (95\% CI, $0.04-0.37) ; p=0.012)$, but not in female patients and control groups.

\section{Discussion}

In this case-control study, we found no association of chronotype and daytime sleepiness with MI, but we 
did find an association with some cardiovascular risk factors such as hypertension and diabetes mellitus, which might lead to MI.

Many studies suggested gender-related differences in sleep, chronotype, and CVD ${ }^{12,19,24,25}$. We examined gender differences in the ESS and MEQ scores in the two groups, but we found none. This may have been due to the high mean age $(>60)$ of our study population; according to Roenneberg et al. and Roenneberg and Merrow ${ }^{26,27}$, after around 50 years of age, genderrelated differences in chronotype and CVD disappear $^{26-28}$. It is considered that estrogens have a cardioprotective effect, and older adults go to sleep earlier than they used to go while they were younger, so they become earlier chronotype ${ }^{26-28}$.

The ESS score was included to assess daytime sleepiness because sleep is an important modulator of cardiovascular and metabolic function ${ }^{14}$. Ahmed et al. ${ }^{29}$ report that the ESS score is a good predictive factor for obstructive sleep apnea, which has a very high incidence in MI patients, so that it might be associated with MI. Our results, with no association of daytime sleepiness with $\mathrm{MI}$, are in concordance with the results of Boden-Albala et al. ${ }^{14}$.

Some studies showed an association between diabetes, hypertension, smoking, and reinfarction with chronotype and daytime sleepiness ${ }^{13,15}$. Our finding of a difference in intermediate chronotype and diabetes mellitus type 2 in female patients is important because of the influence of metabolic syndromes on circadian rhythm and CVD. Diabetes type 2 increases the risk of $\mathrm{CVD}^{13,30}$. Metabolic syndromes, diabetes mellitus type 2, dyslipidemia, and smoking were not associated with ESS score in our study and the study by Whitney et al. ${ }^{31}$, whereas other studies found an association ${ }^{15,32}$. We found no association of evening chronotype with hypertension and diabetes mellitus type 2 in our study, in contrast to the study by Merikanto et al. ${ }^{13}$. Many studies showed that evening chronotype was associated with lower HDL cholesterol levels, metabolic syndrome, and higher stress hormones ${ }^{13,33-35}$. Thus, evening chronotype is associated with metabolic risk factors that predispose to CVD, which is in accordance with our results.

An association of ESS with stroke and vascular events was found in the NOMAS study ${ }^{14}$. Although daytime sleepiness and chronotype for itself are not significant risk factors for MI, ESS and MEQ are associated with risk factors for CVD. Desynchroniza- tion of the circadian system may contribute to metabolic syndrome and complications such as dyslipidemia, glucose intolerance, hypertension, diabetes mellitus type 2, and $\mathrm{CVD}^{36}$.

A limitation of the study was the use of questionnaires because all answers given by the participants referring to chronotype and daytime sleepiness might be a subjective evaluation of the circadian rhythms. The assessment could be more objective if taken by digital recording sleep duration and quality. Another limitation of the study was its sample size. To obtain sufficient power, larger and multicenter studies are needed. For participants in control groups, there is a risk of developing some cardiovascular events, such as angina pectoris or MI.

We found no evidence for chronotype and daytime sleepiness to be directly associated with MI, while some cardiovascular risk factors such as age, dyslipidemia, diabetes mellitus, and smoking might be associated with MEQ or ESS. It is hard to predict developing $\mathrm{MI}$ or some other major cardiovascular events based just on the MEQ or ESS score.

\section{Acknowledgments}

This study was conducted at the Department of Medical Biology and Genetics, Faculty of Medicine, Josip Juraj Strossmayer University of Osijek, and was supported by the UNIOS project entitled Variation in Circadian Rhythm Genes in Patients with Myocardial Infarction at the Josip Juraj Strossmayer University of Osijek, Osijek, Croatia (grant no. IZIP-2014-150).

\section{References}

1. WHO. Global Status Report on Noncommunicable Ciseases 2014. Geneva. 2015.

2. Hrabak Žerjavić V, Kralj V, Dika Ž, Jelaković B. Epidemiology of hypertension, stroke and myocardial infarction in Croatia. Medix. 2010;16(87/88):102-7.

3. Bolooki HM, Askari A. Acute myocardial infarction. In: Carey WD, editors. Current Clinical Medicine. $2^{\text {nd }}$ edn. Cleveland, OH: Sounders Elsevier; 2010:65-71.

4. Guo YF, Stein PK. Circadian rhythm in the cardiovascular system: chronocardiology. Am Heart J. 2003;145(5):779-86, doi: 10.1016/S0002-8703(02)94797-6

5. Partch CL, Green CB, Takahashi JS. Molecular architecture of the mammalian circadian clock. Trends Cell Biol. 2014;24 (2):90-9, doi: 10.1016/j.tcb.2013.07.002

6. Roenneberg T, Wirz-Justice A, Merrow M. Life between clocks: daily temporal patterns of human chronotypes. J Biol Rhythms. 2003;18(1):80-90, doi: 10.1177/0748730402239679. 
7. Maemura K, Layne MD, Watanabe M. Molecular mechanisms of morning onset of myocardial infarction. Ann N Y Acad Sci. 2000;947:398-402.

8. Holmes DR, Aguirre FV, Aplin R, et al. Circadian rhythms in patients with ST-elevation myocardial infarction. Circ Cardiovasc Qual Outcomes. 2010;3(4):382-9, doi: 10.1161/CIRCOUTCOMES.109.913343

9. Thomas M, Sing H, Belenky G, et al. Neural basis of alertness and cognitive performance impairments during sleepiness. I. Effects of $24 \mathrm{~h}$ of sleep deprivation on waking human regional brain activity. J Sleep Res. 2000;4(9):335-52.

10. Ohayon M, Partinen M. Insomnia and global sleep dissatisfaction in Finland.J Sleep Res. 2002;4(11):339-46.

11. Lucas S, Pake K, Brandstaetter R, Balanos G. Circadian variations in cardiovascular function in relation to individual chronotype. Proc Physiol Soc. 2014;31:PCA130.

12. Clark A, Lange T, Hallqvist J, Jennum P, Rod NH. Sleep impairment and prognosis of acute myocardial infarction: a prospective cohort study. Sleep. 2014;37(5):851-8, doi: 10.5665/ sleep.3646

13. Merikanto I, Lahti T, Puolijoki H, et al. Associations of chronotype and sleep with cardiovascular diseases and type 2 diabetes. Chronobiol Int. 2013;30(4):470-7, doi: 10.3109/07420528.2012.741171

14. Boden-Albala B, Roberts ET, Bazil C, et al. Daytime sleepiness and risk of stroke and vascular disease: findings from the Northern Manhattan Study (NOMAS). Circ Cardiovasc Qual Outcomes. 2012;5(4):500-7, doi: 10.1161/CIRCOUTCOMES.111.963801

15. López Messa JB, Garmendia Leiza JR, Aguilar García MD, Andrés de Llano JM, Alberola López C, Ardura Fernández J. Cardiovascular risk factors in the circadian rhythm of acute myocardial infarction. Rev Esp Cardiol. 2004;57(9):850-8, http://www.ncbi.nlm.nih.gov/pubmed/15373991

16. Portaluppi F, Tiseo R, Smolensky MH, Hermida RC, Ayala DE, Fabbian F. Circadian rhythms and cardiovascular health. Sleep Med Rev. 2012;16(2):151-66, doi: 10.1016/j.smrv.2011.04.003

17. Thygesen K, Alpert JS, Jaffe AS, Simoons ML, Chaitman BR, White HD. Third universal definition of myocardial infarction. Nat Rev Cardiol. 2012;9(11):620-33, doi: $10.1038 /$ nrcardio.2012.122

18. Cermakian N, Boivin DB. A molecular perspective of human circadian rhythm disorders. Brain Res Brain Res Rev. 2003; 42(3):204-20, http://www.ncbi.nlm.nih.gov/pubmed/12791440

19. Goel N, Basner M, Rao H, Dinges DF. Circadian rhythms, sleep deprivation, and human performance. Prog Mol Biol Transl Sci. 2013;119:155-90, doi: 10.1016/B978-0-12-396971-2.00007-5

20. Horne JA, Ostberg O. A self-assessment questionnaire to determine morningness-eveningness in human circadian rhythms. Int J Chronobiol. 1976;4(2):97-110, http://www.ncbi.nlm.nih.gov/ pubmed/1027738

21. Horne J, Ostberg O. Individual differences in human circadian rhythms. Biol Psychol. 1977;5(3):179-90.
22. Johns MW. A new method for measure daytime sleepiness: the Epworth sleepiness scale. Sleep. 1991;14(6):540-5.

23. Mapi Research Trust. http://www.mapi-trust.org/. Accessed January 1, 2012.

24. Cappuccio FP, Cooper D, D‘Elia L, Strazzullo P, Miller MA. Sleep duration predicts cardiovascular outcomes: a systematic review and meta-analysis of prospective studies. Eur Heart J. 2011;32(12):1484-92, doi: 10.1093/eurheartj/ehr007

25. Matura LA. Gender and circadian effects of myocardial infarctions. Clin Nurs Res. 2010;19(1):55-70, doi: $10.1177 / 1054773809354371$

26. Roenneberg T, Kuehnle T, Juda M, et al. Epidemiology of the human circadian clock. Sleep Med Rev. 2007;11(6):429-38, doi: 10.1016/j.smrv.2007.07.005

27. Roenneberg T, Merrow M. Entrainment of the human circadian clock. Cold Spring Harb Symp Quant Biol. 2007;72: 293-9, doi: 10.1101/sqb.2007.72.043

28. Touitou Y, Bogdan A. Circadian and seasonal variations of physiological and biochemical determinants of acute myocardial infarction. Biol Rhythm Res. 2007;38(3):169-79, doi: 10.1080/09291010600906075

29. Ben Ahmed H, Boussaid H, Hamdi I, Longo S, Baccar H, Boujnah MR. [Diagnostic accuracy of Epworth sleepiness scale in the acute phase of myocardial infarction.]. Rev Pneumol Clin. 2014;70(3):142-7, doi: 10.1016/j.pneumo.2014.01.003

30. Mornar Jelavić M, Babić Z, Pintarić H, Mišigoj-Duraković M. The role of anthropometry in acute ST-elevation myocardial infarction treated with primary percutaneous coronary intervention. Acta Clin Croat. 2016;55(2):224-32, doi: 10.20471/ acc.2016.55.02.07

31. Whitney CW, Enright PL, Newman AB, Bonekat W, Foley D, Quan SF. Correlates of daytime sleepiness in 4578 elderly persons: the Cardiovascular Health Study. Sleep. 1998;21(1): 27-36, http://www.ncbi.nlm.nih.gov/pubmed/9485530

32. Knutson KL. Sleep duration and cardiometabolic risk: a review of the epidemiologic evidence. Best Pract Res Clin Endocrinol Metab. 2010;24(5):731-43, doi: 10.1016/j.beem.2010.07.001

33. Wong PM, Hasler BP, Kamarck TW, Muldoon MF, Manuck SB. Social jetlag, chronotype, and cardiometabolic risk. J Clin Endocrinol Metab. 2015;100(12):4612-20, doi: 10.1210/jc.2015-2923

34. Yu JH, Yun C-H, Ahn JH, et al. Evening chronotype is associated with metabolic disorders and body composition in middle-aged adults. J Clin Endocrinol Metab. 2015;100(4): 1494-502, doi: 10.1210/jc.2014-3754

35. Lucassen EA, Zhao X, Rother KI, et al. Evening chronotype is associated with changes in eating behavior, more sleep apnea, and increased stress hormones in short sleeping obese individuals. PLoS One. 2013;8(3):e56519, doi: 10.1371/journal.pone.0056519

36. Gómez-Abellán P, Madrid JA, Ordovás JM, Garaulet M. Chronobiological aspects of obesity and metabolic syndrome. Endocrinol Nutr. 2012;59(1):50-61, doi: 10.1016/j.endoen.2011.08.002 


\section{Sažetak}

\section{POVEZANOST CIRKADIJALNOG RITMA S INFARKTOM MIOKARDA}

\section{I. Škrlec, J. Milic, M. Heffer, R. Steiner, B.Peterlin i J. Wagner}

Kardiovaskularne bolesti su vodeći uzrok smrtnosti u svijetu. Pod kontrolom cirkadijalnog sata su humana fiziologija i fiziološka stanja tijekom bolesti. Cilj ovoga istraživanja bio je utvrditi potencijalnu povezanost kronotipa i dnevne pospanosti s infarktom miokarda. Provedeno je istraživanje slučajeva i kontrola na 200 bolesnika s infarktom miokarda te 200 zdravih kontrolnih ispitanika. Od svih ispitanika prikupljeni su podaci o prošloj i trenutnoj medicinskoj anamnezi. Kronotip je procijenjen pomoću upitnika MEQ (Morningness-Eveningness Questionnaire), a dnevna pospanost pomoću Epworthove ljestvice pospanosti (ESS, Eprworth Sleepiness Scale). Prosječna životna dob ispitivane populacije bila je $64 \pm 13$ godina, a $54,5 \%$ ispitanika činili su muškarci. Statistički značajna razlika nije pronađena između bolesnika i kontrola u kronotipu $(58,88 \pm 6,52$ nasuprot 58,46 $\pm 7,78 ; p=0,601$ ) i dnevnoj pospanosti (5 (IQR 4-7,5) nasuprot 6 (IQR 3-8); $p=0,912$ ). Unatoč tome, pronađena je statistički značajna razlika povezana sa čimbenicima rizika za kardiovaskularne bolesti kao što su hipertenzija, dislipidemija i dijabetes. Međutim, u ovom istraživanju nije utvrđena povezanost kronotipa i dnevne pospanosti s infarktom miokarda.

Ključne riječi: Srčanožilne bolesti; Cirkadijalni ritam; Infarkt miokarda; Uzrok smrti; Hrvatska 